\title{
The stimulatory effect of IL-1 $1 \beta$ on the insulin secretion of rat pancreatic islet is not related with iNOS pathway
}

\author{
In-Kyung Jeong ${ }^{1}$, Seung-Hoon $\mathrm{Oh}^{2}$, \\ Jae-Hoon Chung ${ }^{1}$, Yong-Ki Min', \\ Myung-Shik Lee ${ }^{1}$, Moon-Kyu Lee ${ }^{1}$ \\ and Kwang-Won $\mathrm{Kim}^{1,3}$
${ }^{1}$ Division of Endocrinology and Metabolism, Department of Medi- cine, Samsung Medical Center, Sungkyunkwan University School of Medicine, Seoul 135-230, Korea
${ }^{2}$ Clinical research center, Samsung biomedical research institute, Seoul 135-230, Korea
${ }^{3}$ Corresponding author: Tel, +82-2-3410-3430;
Fax, +82-2-3410- 0064; E-mail, kwwkim@smc.samsung.co.kr

\section{Accepted 15 November 2001}

Abbreviations: NO, nitric oxide; NMMA, NG-monomethyl-L-arginine; iNOS, inducible nitric oxide synthase; KRBB, Krebs-Ringer bicarbonate buffer; BSA, bovine serum albumin; CV, coefficient of variation; RT-PCR, reverse transcription-polymerase chain reaction

\begin{abstract}
Interleukin 1 (IL-1) is a pleiotropic cytokine with the potential to destroy pancreatic beta-cells, and thought to be involved in the pathogenesis of type I diabetes mellitus. Expression of inducible nitric oxide synthase (iNOS) and subsequent NO formation induced by IL-1 $\beta$ may impair an islet function in rodents. Inhibition of iNOS may protect against cytokine-induced $\beta$-cell suppression, although cytokines might also induce NO-independent impairment. To examine the role of NO in the IL-1 $\beta$ treated cells, rat islets were treated with various concentrations $(0,0.5,5,50,500$ $\mathrm{pmol} / \mathrm{L})$ of IL-1 $\beta$ with or without NG-monomethyl-Larginine (NMMA; a competitive inhibitor of nitiric oxide synthase) for 2 or $6 \mathrm{~h}$. Insulin secretion was stimulated in islets treated with 5,50 , and $500 \mathrm{pmol} /$ $L$ of IL-1 $\beta$ for $2 h$ and $0.5 \mathrm{pmol} / L$ for $6 \mathrm{~h}$, respectively. The stimulatory effect of IL-1 $\beta$ on the insulin secretion of rat islets was not prevented by NMMA. Nitrate concentration was increased in a time- and concentration-dependent manner. Nitrate production was inhibited by NMMA. iNOS mRNA expression was increased at concentrations more than $5 \mathrm{pmol} / \mathrm{L}$ of IL-1 $\beta$ in a dose dependent manner. iNOS mRNA was detectable after $2 \mathrm{~h}$ and peaked at $6 \mathrm{~h}$ but decreased after $24 \mathrm{~h}$. These results suggested that the stimulatory effect of IL-1 $\beta$ on the insulin secretion of rat
\end{abstract}

islets is independent of iNOS-related NO production of IL-1 $\beta$ and the enzyme activity of nitric oxide synthase.

Keywords: Interleukin-1 $\beta$, islet, insulin, inducible nitric oxide synthase (iNOS), nitric oxide

\section{Introduction}

IL-1 $\beta$ has been demonstrated as a possible mediator of the autoimmune diabetes mellitus through the action of $\beta$-cell cytotoxicity and inhibition of insulin release. When rat pancreatic islets are exposed to $\mathrm{IL}-1 \beta$ in vitro, a paradoxical effect on $\beta$-cell function is ensued. Initially, the stimulation of insulin release was observed at a low concentration and/or short exposure. However, at a high concentration and long exposure, insulin release was drastically inhibited (Spinas et al., 1986; Comens et al., 1987; Spinas et al., 1987; Spinas et al., 1988). This inhibitory effect on insulin release by the high concentration of $\mathrm{IL}-1 \beta$ is closely paralleled with decreased oxidative metabolism and decreased $\mathrm{Ca}^{2+}$ uptake, increased expression of inducible nitric oxide synthase (iNOS) and production of the reactive compound nitric oxide (NO) (Sandler et al., 1991; Welsh et al., 1991; Eizirik et al., 1992; Niemann et al., 1994). Numerous suggestions have been made for a possible mechanism toward the stimulatory effect of IL-1 $\beta$ on insulin secretion: increase of islet oxidative metabolism (Eizirik et al., 1989; Sandler et al., 1990; Eizirik et al., 1995), $\mathrm{Ca}^{2+}$ uptake (Zawalich et al., 1989; Borg et al., 1990), glucose-induced insulin synthesis (Spinas et al., 1987; Zawalich et al., 1989; Zawalich et al., 1991) and stimulation of PKC (Welsh et al., 1989; Eizirik et al., 1995).

Although NO induced by IL-1 $\beta$ may have toxic and inhibitory effects on islets (Corbett et al., 1992; Corbett et al., 1993), recent studies suggested that NO participates in other cellular functions in $\beta$-cell of rat islets (Schmidt et al., 1992; Bilski et al., 1995; Konturek et al., 1997).

Earlier studies indicate that insulin secretion induced by L-arginine in the presence of D-glucose both in vivo and in vitro was halted by potent inhibitors of the NOS, (Schmidt et al., 1992; Bilski et al., 1995), suggesting that NO being a possible mediator of insulin secretion and may be involved in the IL-1 $\beta$-induced insulin stimulatory or inhibitory effect. The aim of the study is to investigate the possible involvement of iNOS pathway in the process of IL-1 $\beta$-induced stimulation of insulin secretion in rat islets. 


\section{Materials and Methods}

\section{Animal and islet isolation}

Pancreas was procured from male Sprague-Dawley rats weighing $200-300 \mathrm{~g}$. Islets were isolated by the modified Lacy and Kostianovsky's method (Lacy et al., 1967).

\section{Islet incubation and static stimulation}

After isolation, the islets were cultured for $24 \mathrm{~h}$ at $37^{\circ} \mathrm{C}$ in $100-\mathrm{mm}$ petri dishes containing M199 medium supplemented with $11.1 \mathrm{mmol} / \mathrm{L}$ glucose, $1 \%$ penicillinstreptomycin-fungizone and $10 \%$ fetal bovine serum (Gibco BRL, Gaithersburg, MD, USA). For three-dimensional (3D) culture, batches of 20 islets were preincubated for $48 \mathrm{~h}$ in 24 well-plates containing millicell (Millipore Corporation, Molsheim, France) with a sponge (Spongostan $^{\circledR}$, Johnson \& Johnson Company, Denmark). After adaptation for $48 \mathrm{~h}$ in 3-D culture, islets were treated with various concentrations of IL-1 $\beta(0,0.5,5$, $50,500 \mathrm{pmol} / \mathrm{L}$ ) with or without $1 \mathrm{mmol} / \mathrm{L}$ NG-monomethyl-L-arginine (a competitive inhibitor of nitirc oxide synthase; NMMA) for 2 and $6 \mathrm{~h}$, respectively. An aliquot of medium was collected and stored at $-20^{\circ} \mathrm{C}$ for insulin and nitrite assay. In order to observe the effect of IL-1 $1 \beta$ (R\&D, Minneapolis, USA) on the glucose-induced static stimulation of insulin, the islets exposed to $\mathrm{IL}-1 \beta$ with or without NMMA were preincubated in Krebs-Ringer bicarbonate buffer (KRBB) supplemented with $3.3 \mathrm{mmol} /$ $\mathrm{L}$ glucose and $0.2 \%$ bovine serum albumin (BSA) (Sigma, St. Louis, MO, USA) for $1 \mathrm{~h}$. The preincubation buffer was removed and glucose-stimulated insulin secretion was initiated by the addition of fresh KRBB containing $3.3 \mathrm{mmol} / \mathrm{L}$ glucose for $1 \mathrm{~h}$. An aliquot of medium was collected for the measurement of basal insulin secretion. Islets were then cultured in KRBB media containing $16.7 \mathrm{mmol} / \mathrm{L}$ glucose for $1 \mathrm{~h}$. An aliquot of medium was collected for the measurement of stimulatory insulin secretion. The basal and stimulatory insulin secretion from IL-1 $\beta$ treated islet was compared with the control. The amount of insulin generated in response to the high-glucose was divided by the amount generated by the low-glucose to yield the mean insulin release stimulation index. The stimulation indices of islets exposed to various concentrations of IL-1 $\beta$ with or without NMMA were compared with that of the control.

\section{Determination of NO synthesis}

NO was measured as the accumulated amount of nitrite in the incubation medium after reduction of nitrate to nitrite with nitrate reductase. Nitrite was determined spectrophotometrically with Griess reagent (Green et al., 1993).

\section{Measurement of insulin}

Insulin in the aliquot of medium was measured by double-antibody radioimmunoassay with rat insulin kit (RI-13K, Linco research Inc, St Louis, MO, USA). Routine intra-assay coefficient of variation (CV) was 4$6 \%$, and interassay CV was $6-10 \%$.

\section{Measurement of iNOS mRNA by reverse transcrip- tion-polymerase chain reaction}

To see the effect of IL-1 $\beta$ on the iNOS expression, total RNA was extracted by using phenol/guanidine isothiocyanate-based RNAzol B (Cinna/Biotecx, Houston, TX, USA) from islets which were treated with different concentrations $(0,0.5,5,50,500 \mathrm{pmol} / \mathrm{L})$ of IL- $1 \beta$ for $2 \mathrm{~h}$ or $6 \mathrm{~h}$. RNA was reverse-transcribed with Superscript revertase transcriptase (Gibco-BRL) in a standard transcription buffer. Aliquots of the generated CDNA were amplified by PCR. The primers for iNOS (5'-GACTGCACAGAATGTTCCAG-3', 5'-TGGCCAGATGTTCCTCTATT-3') and the housekeeping gene GAPDH in rat islets (5'-ACCACAGTCCATGCCATCAC-3', 5'-TCCACCACCCTGTTGCTGTA-3') yielded PCR products of 308 and $452 \mathrm{bp}$, respectively. PCR reactions were performed for 25 cycles in automated DNA thermal cycler using a linked program ( 1 cycle: $45 \mathrm{~s}$ at $94^{\circ} \mathrm{C} 45 \mathrm{~s}$ at $58^{\circ} \mathrm{C}$, and $90 \mathrm{~s}$ at $72^{\circ} \mathrm{C}$ ). The PCR products were separated in $2 \%$ agarose gels. The amount of the PCR product was measured by Multi-analyst (Bio-Rad Inc, CA, USA) using coamplified RT-PCR products for GAPDH as the internal standard. Level of insulin mRNA was corrected according to the intensity of the respective GAPDH signal.

\section{Statistical analysis}

Data are expressed as mean $\pm \mathrm{SE}$. The statistical significance was assessed by the ANOVA test. $P$ value $<0.05$ was considered significant.

\section{Results}

\section{Effect of IL-1 $\beta$ and NMMA on insulin release from rat islets}

The amounts of insulin secretion in cultured rat islets exposed to various concentrations of $\mathrm{IL}-1 \beta(0,0.5,5$, $50,500 \mathrm{pmol} / \mathrm{L})$ with or without NMMA ( $1 \mathrm{mmol} / \mathrm{L})$ for 2 and $6 \mathrm{~h}$ were measured (Figure 1). In the experiments of treatment with IL-1 $\beta$ for $2 \mathrm{~h}$, insulin secretion significantly increased above the concentration of 5 $\mathrm{pmol} / \mathrm{L}$ as compared with the control: $147.0 \pm 26.1 \%$ in 5 $\mathrm{pmol} / \mathrm{L}, 218.7 \pm 56.0 \%$ in $50 \mathrm{pmol} / \mathrm{L}$, and $314.7 \pm 7.7 \%$ in $500 \mathrm{pmol} / \mathrm{L}$. NMMA did not block the stimulatory effect of IL- $1 \beta$ in islets treated with $5,50,500 \mathrm{pmol} / \mathrm{L}$ for $2 \mathrm{~h}$. Insulin secretion of islets treated with IL-1 $\beta$ for $6 \mathrm{~h}$ was also stimulated in $0.5 \mathrm{pmol} / \mathrm{L}(195.7 \pm 31.4 \%)$, but inhibited in $5 \mathrm{pmol} / \mathrm{L}(49.5 \pm 8.6 \%), 50 \mathrm{pmol} / \mathrm{L}(29.5 \pm 8.7 \%)$, and $500 \mathrm{pmol} / \mathrm{L}(25.2 \pm 2.5 \%)$, respectively. NMMA 
A. $2 \mathrm{~h}$

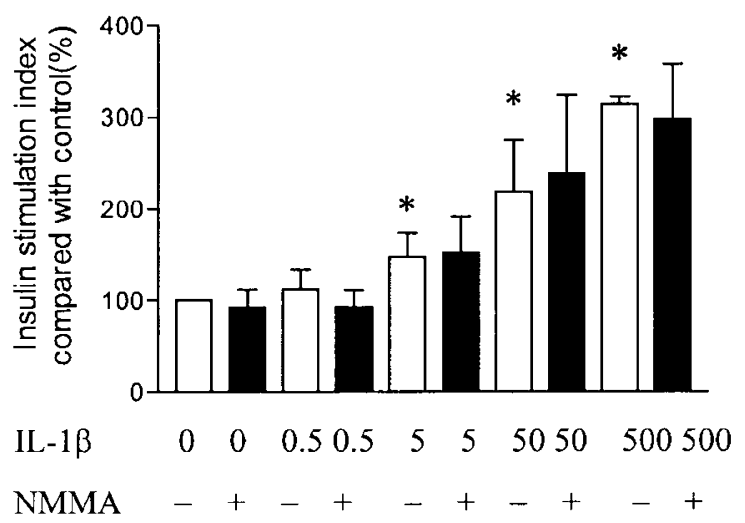

B. $6 \mathrm{~h}$

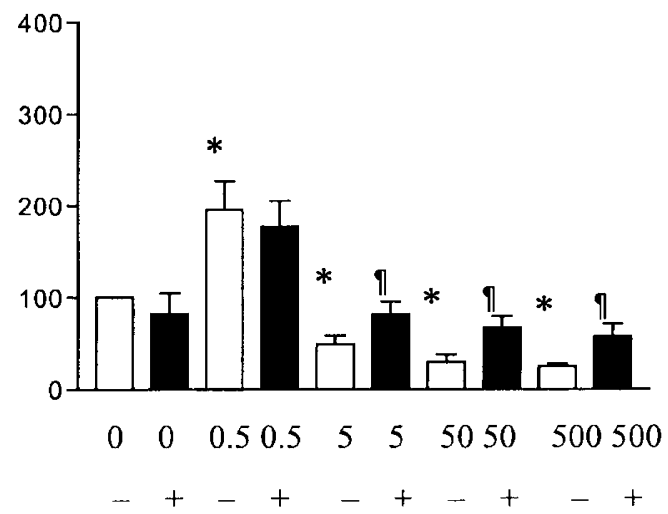

Figure 1. The islets were treated with the various concentrations $(0,0.5,5,50,500$ pmol/L) of IL-1 $\beta$ without $(\square)$ or with $(\square)$ NMMA for $2 \mathrm{~h}(\mathrm{~A})$, and for 6 $h(B)$. After treatment, the islets exposed to IL-1 $\beta$ with or without NMMA were preincubated in Krebs-Ringer bicarbonate buffer (KRBB) supplemented with 3.3 $\mathrm{mmol} / \mathrm{L}$ glucose for $1 \mathrm{~h}$. The preincubation buffer was removed and glucose-stimulated insulin secretion was initiated by the addition of fresh KRBB containing $3.3 \mathrm{mmol} / \mathrm{L}$ glucose for $1 \mathrm{~h}$. An aliquot of medium was collected for measurement of basal insulin secretion. Islets were then cultured in KRBB media containing $16.7 \mathrm{mmo} / \mathrm{L}$ glucose for $1 \mathrm{~h}$. An aliquot of medium was collected for measurement of stimulatory insulin secretion. The amount of insulin generated in response to the high-glucose was divided by the amount generated by the low-glucose to yield the mean insulin release stimulation index. The stimulation indices of islets exposed to various concentrations of IL-1 $\beta$ with or without NMMA were compared with that of the control. Bars are the mean \pm SEM for six experiments. *: $p<0.05$ compared to the control group. I; $p<0.05$ compared to the groups of islets exposed to IL-1 $\beta$ without NMMA.

partially blocked the inhibitory effect of IL-1 $\beta$ in islets treated with $5 \mathrm{pmol} / \mathrm{L}(81.5 \pm 14.2 \%), 50 \mathrm{pmol} / \mathrm{L}(67.2 \pm$ $12.2 \%), 500 \mathrm{pmol} / \mathrm{L}(57.3 \pm 13.5 \%)$ for $6 \mathrm{~h}$. In summary, insulin secretion was significantly stimulated in the islets treated with high concentrations of IL-1 $\beta(5,50,500$ $\mathrm{pmol} / \mathrm{L})$ for $2 \mathrm{~h}$, and low concentration $(0.5 \mathrm{pmol} / \mathrm{L})$ for $6 \mathrm{~h}$ as compared with the control. In contrast, insulin secretion was significantly inhibited in the islets treated with high concentration of IL-1 $13,50,500 \mathrm{pmol} / \mathrm{L})$ for $6 \mathrm{~h}$. NMMA had no effect on the stimulatory effect of IL$1 \beta$, although it significantly reversed the inhibitory effect of IL-1 $\beta$ (Figure 1).

\section{A. $2 \mathrm{~h}$}

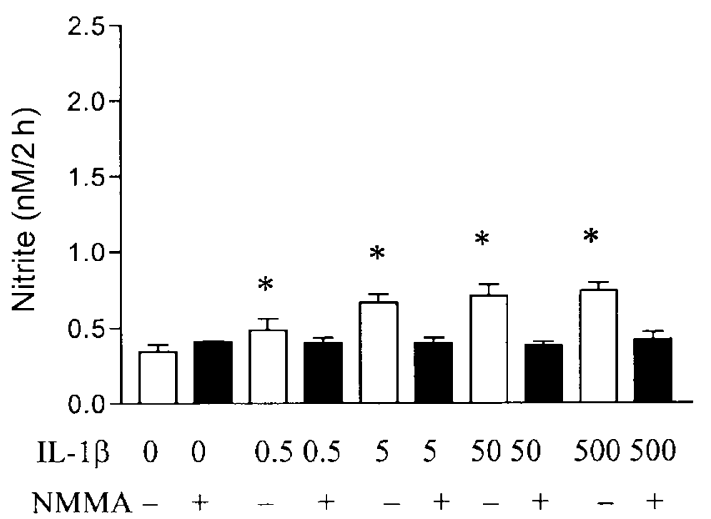

\section{Effect of IL-1 $\beta$ and NMMA on the production of nitric oxide}

The total amount of nitrite was measured in the medium of islets treated with various concentrations of IL-1 $\beta$ with or without NMMA for 2 and $6 \mathrm{~h}$, respectively (Figure 2). Islets treated with IL-1 $\beta$ produced a significantly higher concentration of nitrite than the control. Nitrite concentration increased in a dose dependent manner. Islets exposed to IL-1 $\beta$ for $6 \mathrm{~h}$ produced nitrite to two-fold increase as compared to the islets treated for $2 \mathrm{~h}$. The addition of NMMA to the islets treated with IL-1 $\beta$ suppressed nitrite production to the level of the control.
B. $6 \mathrm{~h}$

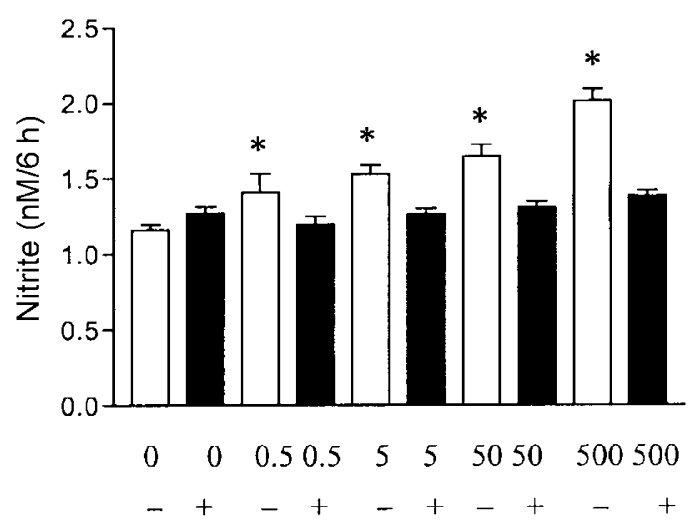

Figure 2. Rat islets were exposed to various concentrations $(0,0.5,5,50,500$ pmol/L) of IL-1 $\beta$ without ( $\square)$ or with ( $\square)$ NMMA for $2 \mathrm{~h}(\mathrm{~A})$ and $6 \mathrm{~h}(\mathrm{~B})$. Nitrite was determined spectrophotometrically with Griess reagent. Bars are the mean \pm SEM for six experiments. *: $p<0.05$ compared to the control islets. 


\section{A. $2 \mathrm{~h}$}
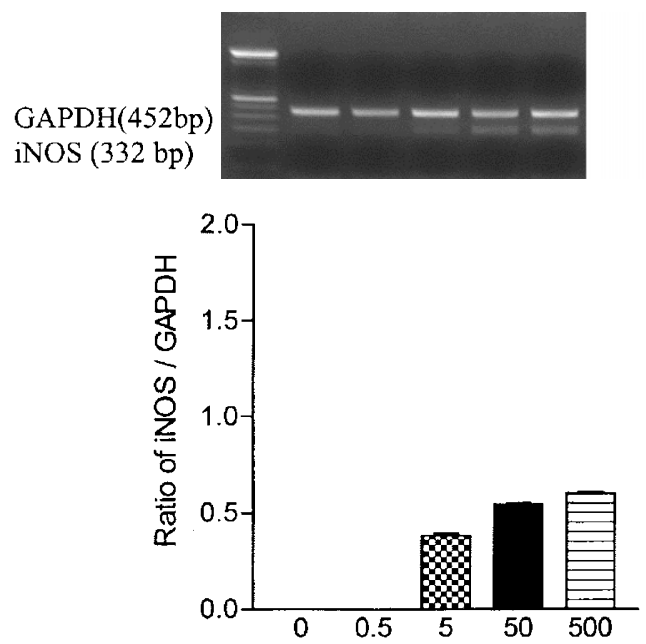

B. $6 \mathrm{~h}$
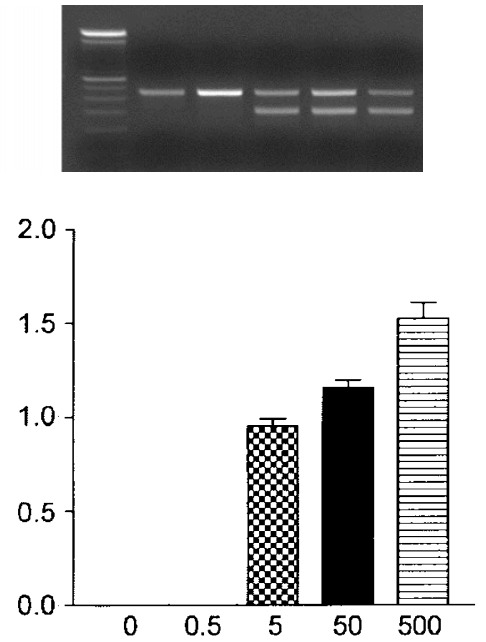

Figure 3. The effect of IL-1 $\beta$ on iNOS mRNA expression in the islets treated with various concentrations $(0,0.5,5,50,500 \mathrm{pmol} / \mathrm{L})$ of IL-1 $\beta$ for $2 \mathrm{~h}(\mathrm{~A})$ and $6 \mathrm{~h}$ (B). Islets were treated with different concentrations of IL-1 $\beta$ for $2 \mathrm{~h}$ and $6 \mathrm{~h}$. RNA was extracted and RT-PCR was performed, as described in Materials and Methods. The pictures shown are representative for 5 similar experiments. PCR band intensities of iNOS mRNA were measured by Multi-analyst and corrected for GAPDH expression. Data are mean \pm SEM from five independent experiments. *: $p<0.05$ compared to the control.

\section{Effect of IL-1 $\beta$ on the iNOS mRNA expression}

To study the relationship between insulin secretion and the expression of iNOS mRNA, we have examined the expression of iNOS mRNA according to different concentrations of IL-1 $\beta$ (Figure 3 ). The degrees of iNOS mRNA expression were displayed by the ratio of GAPDHs signal intensity. The iNOS mRNA began to be expressed at the concentration of $5 \mathrm{pmol} / \mathrm{L}$ of $\mathrm{IL}-1 \beta$, and the degree of expression increased according to the exposure time and the concentration of IL-1 $\beta$. At the low concentration of $0.5 \mathrm{pmol} / \mathrm{L}$ of IL-1 $\beta$, iNOS mRNA was not induced even with $6 \mathrm{~h}$ treatment.

\section{Discussion}

This study confirmed that the stimulatory effect of IL-1 $\beta$ on the insulin secretion in rat pancreatic islet was not accompanied by changes in nitric oxide metabolism, and inhibitors of NO synthase could not prevent the IL$1 \beta$-mediated increase in insulin release.

It has previously been reported that IL-1 $\beta$ induced an initial phase of functional stimulation in rat islets, which is followed after 4-7 $\mathrm{h}$ by a progressive inhibition of insulin release (Spinas et al., 1986; Comens et al., 1987; Spinas et al., 1987; Spinas et al., 1988). It has been known that increased production of NO is an important mediator with the inhibitory effect on insulin secretion (Corbett et al., 1992; Corbett et al., 1993). It has been proposed that NO produced by IL-1 $\beta$ inhibits insulin secretion and glucose oxidation (Southern et al., 1990), suppresses the production of aconitase (mitochondrial enzyme) (Welsh et al., 1992) and cAMP
(Green et al., 1993), increases the production of cGMP in islets (Welsh et al., 1991), and injures DNA (Delaney et al., 1993). Welsh et al. reported that nitric oxide production is a late event and leads to defective insulin release (Welsh et al., 1991).

On the contrary to many reports on the inhibitory effect of NO on insulin secretion, there are several reports about the role of $\mathrm{NO}$ in the stimulation of insulin secretion (Laychock et al., 1991; Schmidt et al., 1994; Laffranchi et al., 1995; Konturek et al., 1997). Laychock et al. (1991) reported that NO is related to the enhanced production of cGMP leading to the beta cell stimulation. The increased cGMP facilitates calcium separation from the mitochondria eventually to increase insulin secretion (Laffranchi et al., 1995). But still there are few data regarding the role of IL-1 $\beta$-induced NO in the contribution to the insulin secretion in the islet. Our data showed that the stimulatory effect of $\mathrm{IL}-1 \beta$ on the insulin secretion is not altered by blocking iNOS-generated NO production. Several possibilities are suggested. One is that $\mathrm{NO}$ is not involved in the process of the stimulatory effect of IL-1 $\beta$ on insulin secretion. Cardozo et al. (2001) reported that $\mathrm{IL}-1 \beta$ is not only involved in iNOS gene expression but also in the expression of many other genes such as hsp-70, MnSOD, and HO-1. Also, reactive oxygen species such as superoxides, hydrogen peroxide and hydroxyl radicals have been suggested to be involved in the catalytic action of nitric oxide synthase to produce NO from L-arginine (Kim et al., 1998).

Interestingly, islets exposed to IL-1 $\beta$ induce complex responses; being protective as well as deleterious (Rho et al., 2000). Therefore, the stimulatory mediator for insulin secretion is not iNOS in the condition of short- 
term and high dose treatment of IL-1 1 .

Schmidt et al. (1994) reported that nearly total block of $\mathrm{NO}$ generation was associated with diminution of insulin secretion. There are several pathways for NO synthesis in the islet, iNOS, eNOS and cNOS. Blocking the activities of iNOS by NMMA not necessarily mean the complete absence of intraislet NO. Thus the possibility of the auxiliary role of $\mathrm{NO}$ in the stimulatory effect on insulin secretion cannot be completely excluded. Further studies should be needed to define the major factors involved in the process of the stimulation of insulin secretion.

Interestingly, in the condition of exposure to long-term and high dose of $\mathrm{IL}-1 \beta$, the inhibitory effect of IL-1 $\beta$ on insulin secretion was reversed to the level of the control by blocking the production of NO. This finding indicated that NO mediates the inhibitory role of IL-1 $\beta$ on the insulin secretion. Based on the data, we can raise another possibility regarding the role of $\mathrm{NO}$ in insulin secretion, that the amount of intraislet NO could determine the effect of stimulation or inhibition. However, in our experimental design, the possibility of involvement of iNOS pathway can be excluded in the stimulatory effect of IL-1 $1 \beta$ on the insulin secretion of the islet.

In our previous study, the expression status of iNOS began to increase at $2 \mathrm{~h}$ and reached the peak at $6 \mathrm{~h}$, but decreased at $24 \mathrm{~h}$ (Jeong et al., 2000). It is similar to other results of Niemann et al. (1994) who reported that iNOS was expressed in $4 \mathrm{~h}$ after suspension in IL$1 \beta$ and increased the most in $6 \mathrm{~h}$, but gradually decreased after 12-48 $\mathrm{h}$. They suggested that the increase of the nitric oxide in the culture medium functions as a negative feedback mechanism to inhibit iNOS.

We have observed that preproinsulin mRNA was paralleled with the stimulatory effect on insulin secretion in previous study (Jeong et al., 2000). According to Andersen et al. (1995), when the islet was incubated in IL-1 $\beta$ for 24 h, 29 or 27 genes, respectively, were up or down regulated by the cytokine along with the expression of iNOS. Among the expressed proteins, some of them were involved in the synthesis of nitric oxide, leading to cytotoxicity. However, the others protected beta cells from being injured and help them recover. In summary, it is assumed that the stimulatory effect of IL$1 \beta$ on insulin secretion is far less related with the expression of iNOS and subsequent synthesis of NO. Further study should be needed to clarify the role of IL$1 \beta$ in insulin secretion in the islet.

\section{Acknowledgments}

This study was supported by Grants of the Good Health R\&D Project (\#HMP-99-E-05-0002), Ministry of Health \& Welfare, R.O.K.

\section{References}

Andersen HU, Larsen PM, Fey SJ, Karlsen AE, MandrupPoulsen T, Nerup J. Two-dimensional gel electrophoresis of rat islet proteins. Interleukin 1 beta-induced changes in protein expression are reduced by L-arginine depletion and nicotinamide. Diabetes 1995;44:400-7

Bilski J, Konturek JW, Konturek SJ, Domschke W. The involvement of endogenous nitric oxide in vagal-cholinergic stimulation of exocrine and endocrine pancreas in dogs. Int $\mathrm{J}$ Pancreatol 1995;18:41-49

Borg LA, Eizirik DL. Short-term exposure of rat pancreatic islets to human interleukin-1 beta increases cellular uptake of calcium. Immunol Lett 1990;26:253-58

Cardozo AK, Kruhoffer M, Leeman R, Orntoft T, Eizirik DL. Identification of novel cytokine-induced genes in pancreatic beta-cells by high-density oligonucleotide arrays. Diabetes 2001;50:909-20

Comens PG, Wolf BA, Unanue ER, Lacy PE, McDaniel ML. Interleukin 1 is potent modulator of insulin secretion from isolated rat islets of Langerhans. Diabetes 1987;36:963-70

Corbett JA, Wang JL, Misko TP, Zhao W, Hickey WF, McDaniel ML. Nitric oxide mediates IL-1 beta-induced islet dysfunction and destruction: prevention by dexamethasone. Autoimmunity 1993;15:145-53

Corbett JA, Wang JL, Sweetland MA, Lancaster JR Jr, McDaniel ML. Interleukin 1 beta induces the formation of nitric oxide by beta-cells purified from rodent islets of Langerhans. Evidence for the beta-cell as a source and site of action of nitric oxide. J Clin Invest 1992;90:2384-91

Delaney CA, Green MH, Lowe JE, Green IC. Endogenous nitric oxide induced by interleukin-1 beta in rat islets of Langerhans and HIT-T15 cells causes significant DNA damage as measured by the 'comet' assay. FEBS Lett 1993;333:29195

Eizirik DL, Sandler S. Human interleukin-1 beta induced stimulation of insulin release from rat pancreatic islets is accompanied by an increase in mitochondrial oxidative events. Diabetologia 1989;32:769-73

Eizirik DL, Sandler S, Welsh N, Juntti-Berggren L, Berggren PO. Interleukin-1 beta-induced stimulation of insulin release in mouse pancreatic islets is related to diacylglycerol production and protein kinase C activation. Mol Cell Endocrinol 1995; 111:159-65

Eizirik DL, Tracey DE, Bendtzen K, Sandler S. Role of receptor binding and gene transcription for both the stimulatory and inhibitory effects of interleukin-1 in pancreatic betacells. Autoimmunity 1992;12:127-33

Green IC, Delaney CA, Cunningham JM, Karmiris V, Southern C. Interleukin-1 beta effects on cyclic GMP and cyclic AMP in cultured rat islets of Langerhans-arginine-dependence and relationship to insulin secretion. Diabetologia 1993;36:9-16

Jeong IK, Oh SH, Kang DM, Chung JH, Min YK, Lee MS, Lee MK, Kim KW. The stimulatory effect of IL-1beta on the insulin 
secretion and its relating factors. J Kor Diabetes Asso 2000;24:431-43

Kim KW, Prevention and treatment of NIDDM. (Smith-Gordon and Nishimura eds), 1992, pp. 69-74, London.

Kim SM, Byun JS, Jung YD, Kang IC, Choi SY, Lee KY. The effects of oxygen radicals on the activity of nitric oxide synthase and guanylate cyclase. Exp Mol Med 1998;31:22126

Konturek JW, Hengst K, Kulesza E, Gabryelewicz A, Konturek SJ, Domschke W. Role of endogenous nitric oxide in the control of exocrine and endocrine pancreatic secretion in humans. Gut 1997;40:86-91

Lacy PE, Kostianovsky M. Method for the isolation of intact islets of Langerhans from the rat pancreas. Diabetes 1967; 16:35-39

Laffranchi R, Gogvadze V, Richter C, Spinas GA. Nitric oxide (nitrogen monoxide, NO) stimulates insulin secretion by inducing calcium release from mitochondria. Biochem Biophys Res Commun 1995;217:584-91

Laychock SG, Modica ME, Cavanaugh CT. L-arginine stimulates cyclic guanosine 3',5'-monophosphate formation in rat islets of Langerhans and RINm5F insulinoma cells: evidence for L-arginine:nitric oxide synthase. Endocrinology 1991;129:3043-52

Niemann A, Bjorklund A, Eizirik DL. Studies on the molecular regulation of the inducible form of nitric oxide synthase (iNOS) in insulin-producing cells. Mol Cell Endocrinol 1994;106:15155

Rho HW, Lee JN, Kim HR, Park BH, Park JW. Protective mechanism of glucose against alloxan-induced beta-cell damage: pivotal role of ATP. Exp Mol Med 2000;31:12-17

Sandler S, Bendtzen K, Eizirik DL, Strandell E, Welsh M, Welsh N. Metabolism and beta-cell function of rat pancreatic islets exposed to human interleukin-1 beta in the presence of a high glucose concentration. Immunol Lett 1990;26:245-51

Sandler S, Bendtzen K, Eizirik DL, Welsh M. Interleukin-6 affects insulin secretion and glucose metabolism of rat pancreatic islets in vitro. Endocrinology 1990;126:1288-94

Sandler S, Eizirik DL, Svensson C, Strandell E, Welsh M, Welsh N. Biochemical and molecular actions of interleukin-1 on pancreatic beta-cells. Autoimmunity 1991;10:241-53

Schmidt HH, Walter U. NO at work. Cell 1994;78:919-25

Schmidt HH, Warner TD, Ishii K, Sheng H, Murad F. Insulin secretion from pancreatic $B$ cells caused by L-arginine- derived nitrogen oxides. Science 1992;255:721-23

Southern C, Schulster D, Green IC. Inhibition of insulin secretion by interleukin-1 beta and tumour necrosis factoralpha via an L-arginine-dependent nitric oxide generating mechanism. FEBS Lett 1990;276:42-44

Spinas GA, Hansen BS, Linde S, Kastern W, Molvig J, Mandrup-Poulsen T, Dinarello CA, Nielsen JH, Nerup J. Interleukin 1 dose-dependently affects the biosynthesis of (pro)insulin in isolated rat islets of Langerhans. Diabetologia 1987;30:474-80

Spinas GA, Mandrup-Poulsen T, Molvig J, Baek L, Bendtzen $\mathrm{K}$, Dinarello CA, Nerup J. Low concentrations of interleukin-1 stimulate and high concentrations inhibit insulin release from isolated rat islets of Langerhans. Acta Endocrinol (Copenh) 1986;113:551-58

Spinas GA, Palmer JP, Mandrup-Poulsen T, Andersen H, Nielsen JH, Nerup J. The bimodal effect of interleukin 1 on rat pancreatic beta-cells--stimulation followed by inhibition--depends upon dose, duration of exposure, and ambient glucose concentration. Acta Endocrinol (Copenh) 1988;119:307-11

Welsh N, Eizirik DL, Bendtzen K, Sandler S. Interleukin-1 beta-induced nitric oxide production in isolated rat pancreatic islets requires gene transcription and may lead to inhibition of the Krebs cycle enzyme aconitase. Endocrinology 1991;129: 3167-73

Welsh N, Nilsson T, Hallberg A, Arkhammar P, Berggren PO, Sandler S. Human interleukin-1 beta stimulates islet insulin release by a mechanism not dependent on changes in phospholipase $\mathrm{C}$ and protein kinase $\mathrm{C}$ activities or $\mathrm{Ca}^{2+}$ handling. Acta Endocrinol (Copenh) 1989;121:698-704

Welsh N, Sandler S. Interleukin-1 beta induces nitric oxide production and inhibits the activity of aconitase without decreasing glucose oxidation rates in isolated mouse pancreatic islets. Biochem Biophys Res Commun 1992;182:333-40

Zawalich WS, Dierolf B, Zawalich KC. Interleukin-1 induces time-dependent potentiation in isolated rat islets: possible involvement of phosphoinositide hydrolysis. Endocrinology 1989;124:720-26

Zawalich WS, Zawalich KC. Interleukin-1 is a potent stimulator of islet insulin secretion and phosphoinositide hydrolysis. Am J Physiol 1989;256:E19-24

Zawalich WS, Zawalich KC. Influence of staurosporine, nitrendipine and monooleoylglycerol on interleukin-1-induced insulin secretion and phosphoinositide hydrolysis. Mol Cell Endocrinol 1991;82:303-11 